\title{
Development of PCR and TaqMan PCR Assays to Detect Pseudomonas corona- faciens, a Causal Agent of Halo Blight of Oats
}

\author{
Ji-Hye An ${ }^{1}$, Young-Hee Noh ${ }^{1}$, Yong-Eon Kim ${ }^{1}$, Hyok-In Lee ${ }^{2}$ and Jae-Soon Cha ${ }^{1 *}$ \\ ${ }^{1}$ Department of Plant Medicine, Chungbuk National University, Cheongju 361-763, Korea \\ ${ }^{2}$ Animal and Plant Quarantine Agency, Anyang 430-016, Korea \\ (Received on September 24, 2014; Revised on February 7, 2015; Accepted on February 7, 2015)
}

Pseudomonas coronafaciens causes halo blight on oats and is a plant quarantine bacterium in many countries, including the Republic of Korea. Using of the certificated seed is important for control of the disease. Since effective detection method of $P$. coronafaciens is not available yet, PCR and TaqMan PCR assays for specific detection of $P$. coronafaciens were developed in this study. PCR primers were designed from the draft genome sequence of $P$. coronafaciens LMG 5060 which was obtained by the next-generation sequencing in this study. The PCR primer set Pc-12-F/Pc-12-R specifically amplified $498 \mathrm{bp}$ from the 13 strains of $P$. coronafaciens isolated in the seven different countries (Canada, Japan, United Kingdom, Zimbabwe, Kenya, Germany, and New Zealand) and the nested primer set Pc-12-neF/Pc-12-ne-R specifically amplified 298 bp from those strains. The target-size PCR product was not amplified from the non-target bacteria with the PCR and nested primer sets. TaqMan PCR with Pc-12-ne-F/Pc-12-ne-R and a TaqMan probe, Pc-taqman, which were designed inside of the nested PCR amplicon, generated $\mathrm{Ct}$ values which in a dose-dependent manner to the amount of the target DNA and the $C t$ values of all the $P$. coronafaciens strains were above the threshold $\mathrm{Ct}$ value for positive detection. The TaqMan PCR generated positive Ct values from the seed extracts of the artificially inoculated oat seeds above $10 \mathrm{cfu} / \mathrm{ml}$ inoculation level. PCR and TaqMan PCR assays developed in this study will be useful tools to detect and identify the plant quarantine pathogen, $P$. coronafaciens.

Keywords : detection, halo blight, oat, PCR, TaqMan PCR

*Corresponding author.

Phone) +82-43-261-2554, FAX) +82-43-271-4414

E-mail)jscha@cbnu.ac.kr
Halo blight, an important disease of the oats is caused by Pseudomonas coronafaciens (Elliott, 1920; Young et al., 1978) and occurs in relatively cool and moist climates leading to substantial economic losses (Marten et al., 1984). It produces light green, oval spots on the leaves of the plant with dark water-soaked centers (Marten et al., 1984; Harder and Haber, 1992; Wallwork, 1992). P. coronafaciens survives on plant debris, soil and seeds (Martens et al., 1984). One of the effective control measures of the disease is prevention of pathogen transfer to the other plants using of the certificated seed (Collins, 2010). Also, P. coronafaciens is a plant quarantine bacterium in many countries, including the republic of Korea. For the certificated seed program and plant quarantine, the specific and effective detection method must be available.

Various tests can be used to detect the seed-borne pathogens, such as plating on selective media, ELISA, seedling grow-out tests, PCR, real-time PCR and DNA microarrays (Walcott, 2003). Among these techniques, plating on selective media and seedling grow-out tests are laborious and time-consuming and the PCR assay is more sensitive and time-saving than ELISA (Cho et al., 2010). In particular, the TaqMan PCR assay, which detects microorganisms quantitatively with a TaqMan probe, has been shown to be successful in detection and identification of seed-borne pathogens (Bella et al., 2008; Schena et al., 2004; FinettiSialer and Ciancio, 2005). For P. coronafaciens, however, effective detection method from oat seeds is not available. Any PCR assay for the specific detection of $P$. coronafaciens has not been published yet.

In this study highly specific PCR and TaqMan PCR assays for detection of $P$. coronafaciens have been developed. For development of the P. coronafaciens - specific PCR assays, information for the unique nucleotide sequence of $P$. coronafaciens must be available. Since there are not many gene sequences of $P$. coronafaciens available in the GenBank, in the present study, next-generation sequencing analysis was used to obtain a whole draft genome 
sequence of $P$. coronafaciens. From the genome sequence, PCR primers were designed for the PCR and TaqMan PCR assays which were specific for the $P$. coronafaciens.

\section{Materials and Methods}

Bacterial strains and cultures. Strains of $P$. coronafaciens isolated in Canada, Japan, United Kingdom, Zimbabwe, Kenya, Germany and New Zealand were obtained from LMG (Belgian Coordinated Collection of Microor- ganisms, Laboratory of Microbiology, University of Gent, Belgium) and from KACC (Korean Agricultural Culture Collection, Rural Develpoment Administration, the Republic of Korea). For the non-target bacteria, strains related to $P$. coronafaciens in genus Pseudomonas or the representative strains of common plant pathogenic bacteria in genus Acidovorax, Pectobacterium, Ralstonia, Rhodococcus, Xanthomonas, and Clavibacter were collected from the various culture collections (Table 1). The bacteria were routinely grown in nutrient agar media containing $8 \mathrm{~g}$ of

Table 1. List of Pseudomonas coronafaciens strains, the non-target bacterial strains of Pseudomonas spp. and other plant-pathogenic bacterial strains used in this study

\begin{tabular}{|c|c|c|c|c|}
\hline Strain $^{\text {ab }}$ & & Host $^{\mathrm{c}}$ & Origin $^{c}$ & Year $^{\mathrm{c}}$ \\
\hline \multicolumn{5}{|l|}{ Acidovorax } \\
\hline avenae subsp. avenae & NCPPB 1011 & Zea mays & USA & 1958 \\
\hline \multicolumn{5}{|l|}{ Clavibacter } \\
\hline michiganensis subsp. incidiosus & NCPPB 1020 & Medicago sativa & Canada & $\mathrm{nk}$ \\
\hline michiganensis subsp. michiganensis & NCPPB 1064 & Lycopersicon esculentum & Italy & 1961 \\
\hline michiganensis subsp. sepedonicus & NCPPB 2137 & Solanum tuberosum & Canada & nk \\
\hline \multicolumn{5}{|l|}{ Pectobacterium } \\
\hline carotovorum subsp. carotovorum & NCPPB 312 & Solanum tuberosum & Denmark & nk \\
\hline \multicolumn{5}{|l|}{ Pseudomonas } \\
\hline \multirow[t]{13}{*}{ coronafacines } & KACC 12133 & nk & nk & nk \\
\hline & KACC 13262 & nk & nk & nk \\
\hline & LMG 2170 & Bromus sp. & Canada & 1962 \\
\hline & LMG 2330 & nk & $\mathrm{nk}$ & 1966 \\
\hline & LMG 5030 & Lolium multiflorum & Japan & 1967 \\
\hline & LMG $5060^{\mathrm{b}}$ & Avena sativa & United Kingdom & 1958 \\
\hline & LMG 5061 & Secale cereale & Canada & 1962 \\
\hline & LMG 5081 & Avena sativa & Zimbabwe & 1971 \\
\hline & LMG 5380 & Avena sativa & Kenya & 1970 \\
\hline & LMG 5449 & Avena sativa & Germany & 1959 \\
\hline & LMG 5452 & Avena sativa & New Zealand & 1969 \\
\hline & LMG 5536 & Avena sativa & United Kingdom & 1965 \\
\hline & LMG 13190 & Avena sativa & nk & $\mathrm{nk}$ \\
\hline savastanoi pv. glycinea & NCPPB 1134 & Glycine javanica & Zimbabwe & 1961 \\
\hline savastanoi pv. phaseolicola & KACC 10575 & Phaseolus vulgaris & Poland & nk \\
\hline savastanoi pv. savastanoi & NCPPB 639 & Olea europaea & Yugoslavia & $\mathrm{nk}$ \\
\hline syringae pv. actinidiae & KACC 10582 & Actinidia chinensis & Rep. of Korea & 1999 \\
\hline syringae pv. antirrhini & ICMP 4303 & Antirrhinum majus & United Kingdom & 1965 \\
\hline syringae pv. aptata & DSM 50252 & Beta vulgaris & $\mathrm{nk}$ & nk \\
\hline syringae pv. atrofaciens & LMG 5095 & Triticum aestivum & New Zealand & 1968 \\
\hline syringae pv. berberidis & NCPPB 2724 & Berberis sp. & New Zealand & 1972 \\
\hline syringae pv. ciccaronei & NCPPB 2355 & Ceratonia siliqua & $\mathrm{nk}$ & 1969 \\
\hline syringae pv. delphinii & ICMP 529 & Delphinium sp. & New Zealand & 1957 \\
\hline syringae pv. dysoxyli & ICMP 545 & Dysoxylum spectabile & New Zealand & 1949 \\
\hline syringae pv. eriobotryae & NCPPB 2331 & Eriobotrya japonica & United Kingdom & 1970 \\
\hline syringae pv. helianthi & NCPPB 1229 & Helianthus annuus & Zambia & 1962 \\
\hline
\end{tabular}


Table 1. Continued

\begin{tabular}{|c|c|c|c|c|}
\hline Strain ${ }^{\mathrm{ab}}$ & & Host $^{c}$ & Origin $^{c}$ & Year $^{\mathrm{c}}$ \\
\hline syringae pv. japonica & ICMP 6305 & Hordeum vulgare & Japan & 1951 \\
\hline syringae pv. lachrymans & ATCC 11965 & Cucumis sativus & $\mathrm{nk}$ & $\mathrm{nk}$ \\
\hline syringae pv. lapsa & ATCC 10859 & Triticum aestivum & nk & 1978 \\
\hline syringae pv. maculicola & ICMP 3935 & Brassica oleracea & New Zealand & 1965 \\
\hline syringae pv. mellea & ICMP 5711 & Nicotiana tabacum & Japan & 1968 \\
\hline syringae pv. mori & ICMP 4331 & Morus alba & Hungary & 1958 \\
\hline syringae pv. morsprunorum & ICMP 5795 & Prunus domestica & $\mathrm{nk}$ & nk \\
\hline syringae pv. myricae & ICMP 7118 & Myrica rubra & Japan & 1978 \\
\hline syringae pv.panici & NCPPB 1498 & Panicum sp. & $\mathrm{nk}$ & $\mathrm{nk}$ \\
\hline syringae pv. papulans & ICMP 4040 & Malus domestica & USA & $\mathrm{nk}$ \\
\hline syringae pv. passiflorae & NCPPB 1386 & Passiflora edulis & New Zealand & 1962 \\
\hline syringae pv. persicae & NCPPB 2761 & Prunus persica & France & 1974 \\
\hline syringae pv. pisi & ICMP 4433 & Pisum sativum & Canada & 1946 \\
\hline syringae pv. ribicola & NCPPB 963 & Ribes aureum & $\mathrm{nk}$ & $\mathrm{nk}$ \\
\hline syringae pv. sesame & NCPPB 1016 & Sesamum indicum & Yugoslavia & $\mathrm{nk}$ \\
\hline syringae pv. syringae & NCPPB 388 & Oryza sativa & Hungary & nk \\
\hline syringae pv. tabaci & ICMP 2835 & Nicotiana tabacum & Hungary & 1959 \\
\hline syringae pv. tagetis & ICMP 4091 & Tagetes erecta & Zimbabwe & 1972 \\
\hline syringae pv. tomato & NCPPB 2683 & Lycopersicon esculentum & New Zealand & 1972 \\
\hline syringae pv. ulmi & NCPPB 632 & Ulmus sp. & Yugoslavia & 1958 \\
\hline \multicolumn{5}{|l|}{ Ralstonia } \\
\hline Solanacearum & NCPPB 339 & Solanum tuberosum & Israel & nk \\
\hline \multicolumn{5}{|l|}{ Rhizobium } \\
\hline radiobacter & DSM 30205 & Malus sp. & nk & 1972 \\
\hline rhizogenes & ATCC 11325 & Malus domestica & $\mathrm{nk}$ & $\mathrm{nk}$ \\
\hline rubi & NCPPB 1854 & Rubus ursinus var. loganobaccus & USA & 1942 \\
\hline vitis & NCPPB 3554 & Vitis vinifera & Australia & 1977 \\
\hline \multicolumn{5}{|l|}{ Rhodococcus } \\
\hline fascians & LMG 3601 & Lillium speciosum cv. Rubrum & Belgium & $\mathrm{nk}$ \\
\hline \multicolumn{5}{|l|}{ Xanthomonas } \\
\hline campestris pv. campestris & KACC 10377 & Brassica oleracea var. capitata & Rep. of Korea & $\mathrm{nk}$ \\
\hline campestris pv. vesicatoria & KACC 11157 & Capsicum annuum & Rep. of Korea & 1999 \\
\hline oryzae pv. oryzae & KACC 10331 & Oryza sativa & Rep. of Korea & nk \\
\hline
\end{tabular}

${ }^{a}$ ATCC, American Type Culture Collection, USA; DSM, DSMZ-Deutsche Sammlung von Mikroorganismen und Zellkulturen GmbH, Germany; ICMP, International Collecti on of Micro-organisms from Plants, Landcare Research, New Zealand; KACC, Korean Agricultural Culture Collection, Rural Development Administration, Rep. of Korea; LMG, Collection of the Laboratorium voor Microbiologie en Microbiele Genetica, Ghent University, Belgium; NCPPB, National Collection of Plant Pathogenic Bacteria, United Kingdom.

${ }^{b}$ This strains was used for genome sequencing by NGS.

nk, not known.

nutrient broth and $15 \mathrm{~g}$ of agar per liter.

Genome sequencing and PCR primer design. Whole genome shotgun sequencing of $P$. coronafaciens LMG 5060 was performed using the Roche/454 pyrosequencing method on a genome sequencer with FLX titanium (Margulies et al., 2005). ORF prediction was performed with Glimmer v. 3.02 (Delcher et al., 2007), Prodigal (Hyatt et al., 2010), and GeneMark.hmm-P (Lukashin and Borodovsky, 1998). ORFs from the draft genome sequence of $P$. coronafaciens LMG 5060 with more than 500 base pairs were BLASTed in the gene bank. To design the primers, candidate ORFs were selected from the ORFs with lower than $80 \%$ nucleotide homology to any known genes. The PCR primers were designed with Primer 3 (v. 0.4.0). The specificity of the primers for $P$. coronafaciens was analyzed by PCR. Nested 
primers and the nucleotide sequence for the TaqMan probe were designed from amplicon sequence of $P$. coronafaciens-specific primers. All the primers and the TaqMan probe used in the study were synthesized by Bioneer Co., Ltd (Daejeon, Korea) or NeoProbe Co., Ltd. (Daejeon, Korea). The TaqMan probe was labeled at the $5^{\prime}$ end with FAM and at the $3^{\prime}$ end with TAMRA.

PCR and TaqMan PCR assays. The genomic DNA was extracted from the bacterial cells using the GeneAll Exgene $^{\mathrm{TM}}$ Cell SV kit (GeneAll Biotechnology, Seoul, Korea) according to the manufacturer's protocol. DNA concentrations were determined with a Qubit ${ }^{\mathrm{TM}}$ fluorometer (Invitrogen $^{\circledR}$, Carlsbad, CA, USA).

The PCR assays used $1 \mu \mathrm{l}$ of template DNA in a $25 \mu \mathrm{l}$ reaction mixture containing $2 \mathrm{mM}$ of Tris- $\mathrm{HCl}(\mathrm{pH} 8.0)$, $10 \mathrm{mM}$ of KCl, $10 \mathrm{uM}$ of EDTA, $100 \mathrm{uM}$ of DTT, $0.05 \%$ Tween 20, 0.05\% Nonidet P-40, 5\% glycerol, $2.5 \mathrm{mM}$ of dNTP, 5 units of Ex Taq DNA (TaKaRa Bio Inc., Shiga, Japan), and $10 \mathrm{pM}$ of each primer. The reactions were performed in a T Gradient Thermal Cycler (Biometra, Göttingen, Germany) programmed for one cycle of $10 \mathrm{~min}$ at $95^{\circ} \mathrm{C}$, followed by 35 cycles of $30 \mathrm{~s}$ at $95^{\circ} \mathrm{C}, 30 \mathrm{~s}$ at $60^{\circ} \mathrm{C}$, and $30 \mathrm{~s}$ at $72^{\circ} \mathrm{C}$, with a final extension step for $7 \mathrm{~min}$ at $72^{\circ} \mathrm{C}$. The amplicons were analyzed by electrophoresis in a $2 \%$ agarose gel in TAE buffer.

The TaqMan PCR assay was carried out using $2 \mu \mathrm{l}$ of DNA template, $8.5 \mu$ l of Premix Ex Taq (TaKaRa Bio Inc., Shiga, Japan), $1 \mu$ l of TaqMan probe (10 pmoles/ $\mu$ l), $0.5 \mu \mathrm{l}(10 \mathrm{pmoles} / \mu \mathrm{l})$ of each nested primer, and $12.5 \mu \mathrm{l}$ of DEPC-DW (Bioneer, Daejeon, Korea). Real-time PCR amplifications were performed in a Smart $\mathrm{Cycler}^{\mathrm{TM}}$ System (Cepheid, Sunnyvale, CA, USA) with 40 cycles at $95^{\circ} \mathrm{C}$ for $30 \mathrm{sec}$ and $60^{\circ} \mathrm{C}$ for $20 \mathrm{sec}$ after initial incubation for 30 sec at $95^{\circ} \mathrm{C}$.

Oat seed preparation and extraction. Prior to inoculation, the oat seeds (cultivar Samhan, provided by the National Honam Agricultural Experiment Station in Korea) were surface sterilized by soaking in $70 \%$ ethanol for 30 minute and $1.2 \%$ sodium hypochlorite solution for 1 hour. The oats seeds were washed 3 times with sterilized water and dried completely in clean bench. Twelve grams of the surface-sterilized oat seeds were artificially inoculated by shaking (120 rpm) in $45 \mathrm{ml}$ of $P$. coronafaciens $\mathrm{LMG}$ 5060 suspension for $24 \mathrm{~h}$. The seeds were dried by leaving them in a clean bench for $20 \mathrm{~h}$. The bacterial pathogen was extracted from the artificially inoculated oat seeds as described previously (Maes et al., 1996). The seeds (12 g) were shaken in $12 \mathrm{ml}$ of cold aqueous saline $(0.85 \%$
$\mathrm{NaCl}$ ) containing a drop of Tween 20 for $5 \mathrm{~min}$ on a rotator shaker $(180 \mathrm{rpm})$ at room temperature. The extracts were treated at $95^{\circ} \mathrm{C}$ for $7 \mathrm{~min}$ and used in the PCR assay or stored at $-20^{\circ} \mathrm{C}$.

\section{Results}

Primer and PCR specificity. To obtain specific primers of the $P$. coronafaciens, the draft genome sequence of $P$. coronafaciens LMG 5060 was constructed by genome shotgun sequencing in this study. The draft genome sequence was deposited at NCBI GenBank (accession number: JSED00000000). The 36 primer sets were designed from the ORFs in total 2028 contigs which showed low homology to that of known genes in GenBank and the primer specificities for $P$. coronafaciens were checked by PCR assays with target and non-target bacterial strains. Among the primers tested, the Pc-12-F (5'-GATTGCGTCATATGCAACAT-3') and Pc-12-R (5'-AATAGCAGATCCAGCCAAAG-3') primer sets amplified a $498 \mathrm{bp}$ in all 13 strains of $P$. coronafaciens (Fig. 1), whereas target-size DNA was not amplified in non-target bacteria, including $30 \mathrm{P}$. syringae pathovars, 3 P. savastanoi pathovars, and 16 other pathogenic bacteria (Fig. 2). The nested primers, Pc-12-ne-F (5'-AACGACGGGCTGCAGTTTAT-3') and Pc-12-ne-R (5'-AACGTGATAGCAGCCCCACT-3'), were designed from the Pc-12-F/Pc-12-R amplicon. The PCR assay was conducted with the Pc-12-ne-F/Pc-12-ne-R nested primer set and genomic DNA amplified the 298 bp in all 13 strains of $P$. coronafaciens (supplement Fig. 1), whereas targetsize DNA was not amplified in any non-target bacteria, including $30 P$. syringae pathovars, 3 P. savastanoi path-

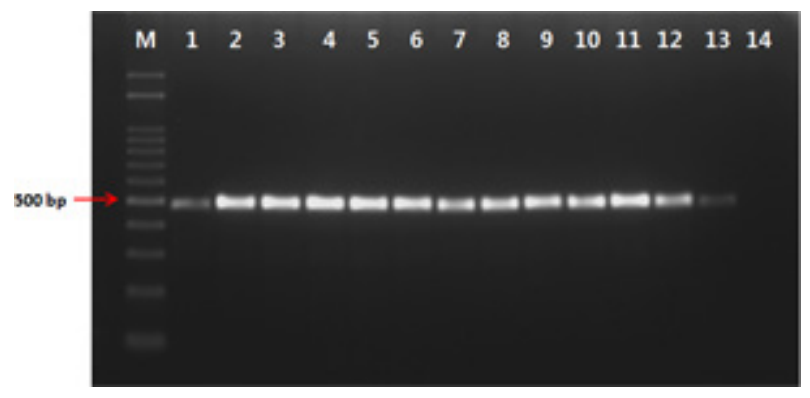

Fig. 1. Gel electrophoresis of the polymerase chain reaction products formed with primer Pc-12-F/Pc-12-R and bacterial DNA of Pseudomonas coronafaciens strains. Lanes 1 13, P. coronafaciens LMG 5060, KACC 13262, KACC 12133, LMG 2170, LMG 5030, LMG 5061, LMG 5081, LMG 5380, LMG 5449, LMG 5452, LMG 5536, LMG 13190, LMG 2330; lane 14, water as a negative control. 


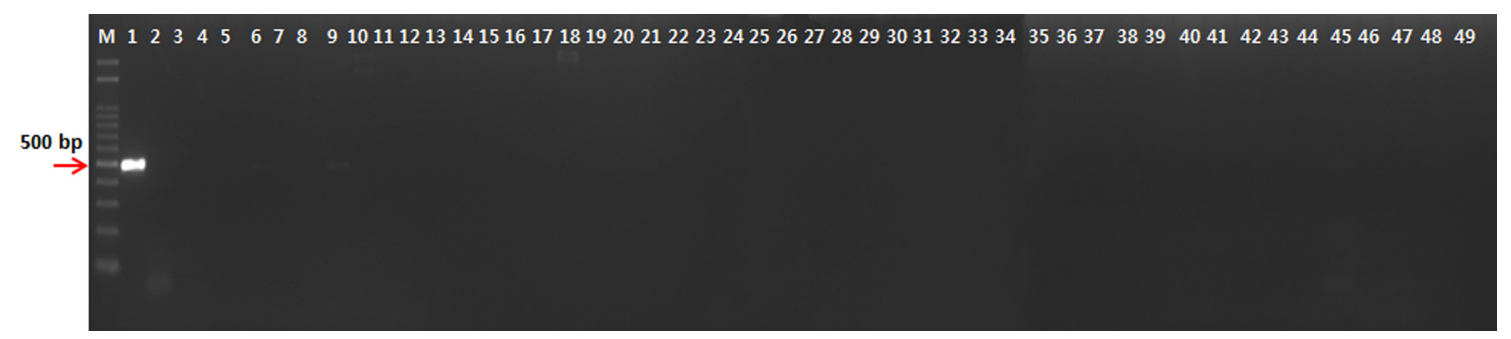

Fig. 2. Gel electrophoresis of the polymerase cain reaction products formed with primer Pc-12-F/Pc-12-R and total DNA of lane 1, Pseudomonas coronafaciens LMG 5060, lanes 2-31, P. syringae pvs, actinidiae KACC 10582, antirrhini ICMP 4303, aptata DSM 50252, atrofaciens ICMP 4394, berberidis NCPPB 2724, ciccaronei NCPPB 2355, delphhinii ICMP 529, dysoxyli ICMP 545, eriobotyae NCPPB 2331, helianthi NCPPB 1229, japonica ICMP 6305, lachrymans ATCC 11965, lapsa ATCC 10859, maculicola ICMP 3935 , mellea ICMP 5711, mori ICMP 4331, morsprunorum ICMP 5795, myricae ICMP 7118, panici NCPPB 1498, papulans ICMP 4040, passiflorae NCPPB 1386, persicae NCPPB 2761, pisi ICMP 4433, ribicola NCPPB 963, sesami NCPPB 1016, syringae NCPPB 388, tabaci ICMP 2835, tagetis ICMP 4091, tomato NCPPB 2683, ulmi NCPPB 632; lanes 32 34, P. savastanoi pvs. glycinea NCPPB 1134 , pahseolicola KACC 10575, and savastanoi NCPPB 639; lane 35, Acidovorax avenae subsp. avenae NCPPB 1011; lanes 36-38, Clavibacter michiganensis subsp. insidiosus NCPPB 1020, michiganensis NCPPB 1064, sepedonicus NCPPB 2137; lane 39, Pectobacterium carotovorum subsp. carotovorum, NCPPB 312; lanes 40-43, Rhizobium radiobacter DSM 30205, $R$. rhizogenes ATCC 11325, $R$. rubi NCPPB 1854, $R$. vitis NCPPB 3554; lane 44, Rhodococcus fascians LMG 3601; lane 45, Ralstonia solanacearum NCPPB 339; lanes 46-47, Xanthomonas campestris pvs. campestris KACC 10377, vesicatoria KACC 11157; lane 48, X. oryzae pv. oryzae KACC 10331; lane 1, P. coronafaciens LMG 5060, as a positive control; lane 49, water as a negative control.

ovars, and 16 other pathogenic bacteria (Supplement Fig. 2).

TaqMan PCR specificity. To reduce the rate of false-positives and quantitatively detect $P$. coronafaciens, a TaqMan probe, Pc-taqman (5'-TGAAACCGCCGAAACGGTCT$3^{\prime}$ ), was designed from the sequence of the Pc-12-ne-F/Pc12-ne-R amplicon. The real-time PCR with Pc-12-ne-F/ Pc-12-ne-R and Pc-taqman generated $\mathrm{Ct}$ values in a dosedependent for $10 \mathrm{ng}-10 \mathrm{pg}$ of $P$. coronafaciens LMG 5060' genomic DNA. The $r^{2}$ of the linear regression was 0.994 (Fig. 3A).

The specificity of the TaqMan PCR was checked with the target and non-target bacteria. In the TaqMan PCR assays, 10 -fold diluted DNAs (10 ng to $10 \mathrm{pg}$ ) of $P$. coronafaciens LMG 5060 were used as standard, and $10 \mathrm{ng}$ of DNAs of the other bacterial strains were used. The Ct values of the $13 P$. coronafaciens strains were 22-28 cycles (Fig. 3B and Table 2), whereas the average $\mathrm{Ct}$ values of the DNA of 49 non-target bacterial strains were more than 37 cycles (Table 2). The Ct values of the target and non-target bacteria were well separated into two different groups.

TaqMan PCR detection of $\boldsymbol{P}$. coronafaciens from the artificially inoculated oat seeds. The TaqMan PCR assay developed in this study was applied to detect $P$. coronafaciens from the oat seeds. Since the seeds naturally infested
(A)



(B)



Fig. 3. Sensitivity and specificity of the TaqMan real-time PCR with primer, Pc-12-ne-F/Pc-12-ne-R and TaqMan probe, Pc-taqman. (A) The linear regression generated by ten-fold dilution of DNA of Pseudomonas coronafaciens LMG 5060 and (B) TaqMan PCR with DNAs (circle dot) of $P$. coronafaciens LMG 5060, and $P$. coronafaciens strains (square dot): $P$. coronafaciens KACC 13262, KACC 12133, LMG 2170, LMG 5030, LMG 5061, LMG 5081, LMG 5380, LMG 5449, LMG 5452, LMG 5536, LMG 13190, and LMG 2330. 
Table 2. The Ct values of Pseudomonas coronafaciens strains, the non-target bacterial strains and the seed extracts from artificially inoculated oat seeds with Pseudomonas coronafaciens LMG 5060 which were obtained by the TaqMan PCR assays

\begin{tabular}{|c|c|c|c|}
\hline Samples & & DNA conc. & Mean $\mathrm{Ct}^{\mathrm{a}}$ \\
\hline \multirow[t]{16}{*}{ Pseudomonas coronafaciens } & LMG 5060 (STD) & $10 \mathrm{ng}$ & $22.8 \pm 0.1$ \\
\hline & & $1 \mathrm{ng}$ & $28.7 \pm 2.5$ \\
\hline & & $100 \mathrm{pg}$ & $31.3 \pm 1.5$ \\
\hline & & $10 \mathrm{pg}$ & $36.5 \pm 3.3$ \\
\hline & KACC 12133 & $10 \mathrm{ng}$ & $22.5 \pm 0.1$ \\
\hline & KACC 13262 & $10 \mathrm{ng}$ & $22.7 \pm 0.2$ \\
\hline & LMG 2170 & $10 \mathrm{ng}$ & $23.3 \pm 0.1$ \\
\hline & LMG 2330 & $10 \mathrm{ng}$ & $27.1 \pm 0.7$ \\
\hline & LMG 5030 & $10 \mathrm{ng}$ & $22.8 \pm 0.3$ \\
\hline & LMG 5061 & $10 \mathrm{ng}$ & $28.0 \pm 1.0$ \\
\hline & LMG 5081 & $10 \mathrm{ng}$ & $25.8 \pm 2.1$ \\
\hline & LMG 5380 & $10 \mathrm{ng}$ & $24.7 \pm 0.4$ \\
\hline & LMG 5449 & $10 \mathrm{ng}$ & $25.1 \pm 0.4$ \\
\hline & LMG 5452 & $10 \mathrm{ng}$ & $25.5 \pm 2.0$ \\
\hline & LMG 5536 & $10 \mathrm{ng}$ & $23.5 \pm 0.6$ \\
\hline & LMG 13190 & $10 \mathrm{ng}$ & $27.9 \pm 1.5$ \\
\hline \multicolumn{4}{|l|}{ Non-target bacterial strains } \\
\hline Acidovorax avenae subsp. avenae & NCPPB 1011 & $10 \mathrm{ng}$ & $39.1 \pm 1.7$ \\
\hline Clavibacter michiganensis subsp. incidiosus & NCPPB 1020 & $10 \mathrm{ng}$ & $>40$ \\
\hline Clavibacter michiganensis subsp. michiganensis & NCPPB 1064 & $10 \mathrm{ng}$ & $>40$ \\
\hline Clavibacter michiganensis subsp. sepedonicus & NCPPB 2137 & $10 \mathrm{ng}$ & $>40$ \\
\hline Pectobacterium carotovorum subsp. carotovorum & NCPPB 312 & $10 \mathrm{ng}$ & $>40$ \\
\hline Pseudomonas savastanoi pv. glycinea & NCPPB 1134 & $10 \mathrm{ng}$ & $>40$ \\
\hline Pseudomonas savastanoi pv. phaseolicola & KACC 10575 & $10 \mathrm{ng}$ & $39.5 \pm 0.9$ \\
\hline Pseudomonas savastanoi pv. savastanoi & NCPPB 639 & $10 \mathrm{ng}$ & $>40$ \\
\hline Pseudomonas syringae pv. actinidiae & KACC 10582 & $10 \mathrm{ng}$ & $>40$ \\
\hline Pseudomonas syringae pv. antirrhini & ICMP 4303 & $10 \mathrm{ng}$ & $>40$ \\
\hline Pseudomonas syringae pv. aptata & DSM 50252 & $10 \mathrm{ng}$ & $>40$ \\
\hline Pseudomonas syringae pv. atrofaciens & LMG 5095 & $10 \mathrm{ng}$ & $>40$ \\
\hline Pseudomonas syringae pv. berberidis & NCPPB 2724 & $10 \mathrm{ng}$ & $37.8 \pm 1.9$ \\
\hline Pseudomonas syringae pv. ciccaronei & NCPPB 2355 & $10 \mathrm{ng}$ & $39.6 \pm 0.8$ \\
\hline Pseudomonas syringae pv. delphinii & ICMP 529 & $10 \mathrm{ng}$ & $39.5 \pm 0.9$ \\
\hline Pseudomonas syringae pv. dysoxyli & ICMP 545 & $10 \mathrm{ng}$ & $39.3 \pm 1.3$ \\
\hline Pseudomonas syringae pv. eriobotryae & NCPPB 2331 & $10 \mathrm{ng}$ & $>40$ \\
\hline Pseudomonas syringae pv. helianthi & NCPPB 1229 & $10 \mathrm{ng}$ & $39.9 \pm 0.2$ \\
\hline Pseudomonas syringae pv. japonica & ICMP 6305 & $10 \mathrm{ng}$ & $>40$ \\
\hline Pseudomonas syringae pv. lachrymans & ATCC 11965 & $10 \mathrm{ng}$ & $>40$ \\
\hline Pseudomonas syringae pv. lapsa & ATCC 10859 & $10 \mathrm{ng}$ & $>40$ \\
\hline Pseudomonas syringae pv. maculicola & ICMP 3935 & $10 \mathrm{ng}$ & $>40$ \\
\hline Pseudomonas syringae pv. mellea & ICMP 5711 & $10 \mathrm{ng}$ & $38.7 \pm 1.3$ \\
\hline Pseudomonas syringae pv. mori & ICMP 4331 & $10 \mathrm{ng}$ & $>40$ \\
\hline Pseudomonas syringae pv. morsprunorum & ICMP 5795 & $10 \mathrm{ng}$ & $>40$ \\
\hline Pseudomonas syringae pv. myricae & ICMP 7118 & $10 \mathrm{ng}$ & $>40$ \\
\hline Pseudomonas syringae pv. panici & NCPPB 1498 & $10 \mathrm{ng}$ & $>40$ \\
\hline Pseudomonas syringae pv. papulans & ICMP 4040 & $10 \mathrm{ng}$ & $>40$ \\
\hline Pseudomonas syringae pv. passiflorae & NCPPB 1386 & $10 \mathrm{ng}$ & $39.7 \pm 0.6$ \\
\hline Pseudomonas syringae pv. persicae & NCPPB 2761 & $10 \mathrm{ng}$ & $>40$ \\
\hline
\end{tabular}


Table 2. Continued

\begin{tabular}{|c|c|c|c|}
\hline Samples & & DNA conc. & Mean $\mathrm{Ct}^{\mathrm{a}}$ \\
\hline Pseudomonas syringae pv. pisi & ICMP 4433 & $10 \mathrm{ng}$ & $>40$ \\
\hline Pseudomonas syringae pv. ribicola & NCPPB 963 & $10 \mathrm{ng}$ & $>40$ \\
\hline Pseudomonas syringae pv. sesami & NCPPB 1016 & $10 \mathrm{ng}$ & $>40$ \\
\hline Pseudomonas syringae pv. syringae & NCPPB 388 & $10 \mathrm{ng}$ & $>40$ \\
\hline Pseudomonas syringae pv. tabaci & ICMP 2835 & $10 \mathrm{ng}$ & $>40$ \\
\hline Pseudomonas syringae pv. tagetis & ICMP 4091 & $10 \mathrm{ng}$ & $>40$ \\
\hline Pseudomonas syringae pv. tomato & NCPPB 2683 & $10 \mathrm{ng}$ & $>40$ \\
\hline Pseudomonas syringae pv. ulmi & NCPPB 632 & $10 \mathrm{ng}$ & $39.8 \pm 0.3$ \\
\hline Ralstonia solanacearum & NCPPB 339 & $10 \mathrm{ng}$ & $>40$ \\
\hline Rhizobium radiobacter & DSM 30205 & $10 \mathrm{ng}$ & $>40$ \\
\hline Rhizobium rhizogenes & ATCC 11325 & $10 \mathrm{ng}$ & $>40$ \\
\hline Rhizobium rubi & NCPPB 1854 & $10 \mathrm{ng}$ & $>40$ \\
\hline Rhizobium vitis & NCPPB 3554 & $10 \mathrm{ng}$ & $>40$ \\
\hline Rhodococcus fascians & LMG 3601 & $10 \mathrm{ng}$ & $>40$ \\
\hline Xanthomonas campestris pv. campestris & KACC 10377 & $10 \mathrm{ng}$ & $>40$ \\
\hline Xanthomonas campestris pv. vesicatoria & KACC 11157 & $10 \mathrm{ng}$ & $>40$ \\
\hline Xanthomonas oryzae pv. oryzae & KACC 10331 & $10 \mathrm{ng}$ & $>40$ \\
\hline \multicolumn{4}{|l|}{ Seed extracts from oat seeds inoculated in } \\
\hline $10^{8} \mathrm{cfu} / \mathrm{ml}$ cell suspension & & - & $21.2 \pm 0.5$ \\
\hline $10^{7} \mathrm{cfu} / \mathrm{ml}$ cell suspension & & - & $21.4 \pm 0.2$ \\
\hline $10^{6} \mathrm{cfu} / \mathrm{ml}$ cell suspension & & - & $21.3 \pm 0.2$ \\
\hline $10^{5} \mathrm{cfu} / \mathrm{ml}$ cell suspension & & - & $22.5 \pm 0.5$ \\
\hline $10^{4} \mathrm{cfu} / \mathrm{ml}$ cell suspension & & - & $24.2 \pm 0.7$ \\
\hline $10^{3} \mathrm{cfu} / \mathrm{ml}$ cell suspension & & - & $25.1 \pm 1.1$ \\
\hline $10^{2} \mathrm{cfu} / \mathrm{ml}$ cell suspension & & - & $29.2 \pm 0.3$ \\
\hline $10 \mathrm{cfu} / \mathrm{ml}$ cell suspension & & - & $32.2 \pm 0.7$ \\
\hline control (water treatment) & & - & $>40$ \\
\hline
\end{tabular}

with the pathogen were not available, the artificially inoculated oat seeds were used. TaqMan PCR with the seed extracts generated a range of mean $\mathrm{Ct}$ values from 21.2 for $10^{8} \mathrm{cfu} / \mathrm{ml}$-inoculated seed extracts to 32.2 for $10 \mathrm{cfu} / \mathrm{ml}-$ inoculated seed extracts (Table 2). Since Ct values of all the non-target bacteria used in this study were larger than 37 cycles, the TaqMan PCR can detect $P$. coronafaciens from the seed extract of the artificially inoculated oat seeds above $10 \mathrm{cfu} / \mathrm{ml}$ inoculation level.

Estimation of the recovery number of P. coronafaciens from the artificial inoculated seed extract was tried with several different ways, but the accurate enumeration of $P$. coronafaciens from the seed extract failed because the many non-target-shape colonies were cultured on the culture plate and the selective medium for $P$. coronafaciens was not available. Surface sterilization of the oat seeds prior to artificial inoculation could not prevent growth of some non-target bacteria on the recovery culture plates.

\section{Discussion}

Highly specific PCR and TaqMan PCR assays have been developed in this study to detect $P$. coronafaciens, the halo blight pathogen of oats. Since $P$. coronafaciens is a plant quarantine bacterium in many countries and using of the certificated seed is important for the disease control, developments of these assays are significant for the management of halo blight of oats.

To obtain specific primers of the $P$. coronafaciens, a genome-wide search was conducted from the draft genome sequence of $P$. coronafaciens which was constructed by genome shotgun sequencing in this study. A specific primer, Pc-12-F/Pc-12-R, was designed from ORF 7 in contig 7 of the draft genome sequence of $P$. coronafaciens (NCBI GenBank accession number: JSED00000000). ORF 7 was 1341 nucleotides long, and no significant homologous gene was found in the NCBI GenBank database. PCRs with Pc- 
12-F/Pc-12-R and Pc-12-ne-F/Pc-12-ne-R generated the target size DNA from all 13 strains of $P$. coronafaciens isolated in seven countries. The target-size DNA was not amplified in 49 strains of non-target bacteria. The $\mathrm{Ct}$ values of the target and non-target bacteria were well separated in the TaqMan PCR. The homology of the ORFs in which PCR was designed and the results of the PCR and TaqMan PCR indicate that the primer sequences and PCR assays developed in this study are highly specific to $P$. coronafaciens.

TaqMan PCR was applied to detect the target pathogen from artificially inoculated oat seeds. TaqMan PCR generated the $P$. coronafaciens-positive $\mathrm{Ct}$ values in the seed extracts obtained from oat seeds inoculated in $10 \mathrm{cfu} / \mathrm{ml}$ and above. Although detection sensitivity of this TaqMan PCR cannot compared to the previously published results because detection of $P$. coronafaciens from oat seeds has not been published, positive detection of the seed extracts obtained from oat seeds inoculated in $10 \mathrm{cfu} / \mathrm{ml} P$. coronafaciens LMG 5060 suspension and above is thought to be a quite high sensitivity and can apply to seed test and plant quarantine service.

\section{Acknowledgements}

This work was supported by the research grant of Chungbuk National University in 2012.

\section{References}

Bella, P., Licciardello, G., Tessitori, M. and Catara, V. 2008. A real-time PCR quantitative detection assay for Pseudomonas savastanoi pv. nerii in Nerium oleander. Phytopathol. Mediterr. 47:204-213.

Cho, J. H., Jeong, M. J., Song, M. J., Yim, K. O., Lee, H. I., Kim, J. H., Baeg, J. H. and Cha, J. S. 2010. Development of PCR Primers to Detect Pseudomonas savastanoi pv. phaseolicola from the Bean Seeds. Res. Plant Dis. 16:129-135.

Collins, D. J. 2010. Oat Diseases in Alabama: Circular ANR-631. Alabama Cooperative Extension Service.

Delcher, A. L., Bratke, K. A., Powers, E. C. and Salzberg, S. L. 2007. Identifying bacterial genes and endosymbiont DNA with Glimmer. Bioinformatics 23:673-679.
Elliott, C. 1920. Halo-blight of oats. J. Agric. Res. 19:139-172.

Finetti-Sialer, M. M. and Ciancio, A. 2005. Isolate-specific detection of Grapevine fan-leaf virus from Xiphinema index through DNA-based molecular probes. Phytopathology 95:262-268

Harder, D. E. and Haber, S. 1992. Oat diseases and pathologic techniques. In Oat Science and Technology 33:307-402.

Hyatt, D., Chen, G. L., Locascio, P. F., Land, M. L., Larimer, F. W. and Hauser, L. J. 2010. Prodigal: prokaryotic gene recognition and translation initiation site identification. BMC Bioinform. 11:119-129.

Lukashin, A. and Borodovsky, M. 1998. GeneMark.hmm: new solutions for gene finding. Nucleic Acids Res. 26:1107-1115.

Maes, M., Garbeva, P. and Kamoen, O. 1996. Recognition and detection in seed of the Xanthomonas pathogens that cause cereal leaf streak using rDNA spacer sequences and polymerase chain reaction. Phytopathology 86:63-69.

Margulies, M., Egholm, M., Altman, W. E., Attiya, S., Bader, J. S., Bemben, L. A., Berka, J., Braverman, M. S., Chen, Y. J., Chen, Z., Dewell, S. B., Du, L., Fierro, J. M., Gomes, X. V., Godwin, B. C., He, W., Helgesen, S., Ho, C. H., Ho, C. H., Irzyk, G. P., Jando, S. C., Alenquer, M. L., Jarvie, T. P., Jirage, K. B., Kim, J. B., Knight, J. R., Lanza, J. R., Leamon, J. H., Lefkowitz, S. M., Lei, M., Li, J., Lohman, K. L., Lu, H., Makhijani, V. B., McDade, K. E., McKenna, M. P., Myers, E. W., Nickerson, E., Nobile, J. R., Plant, R., Puc, B. P., Ronan, M. T., Roth, G. T., Sarkis, G. J., Simons, J. F., Simpson, J. W., Srinivasan, M., Tartaro, K. R., Tomasz, A., Vogt, K. A., Volkmer, G. A., Wang, S. H., Wang, Y., Weiner, M. P., Yu, P., Begley, R. F. and Rothberg, J. M. 2005. Genome sequencing in microfabricated highdensity picolitre reactors. Nature 437:376-380.

Martens, J. W., Seaman, W. L. and Atkinson, T. G. 1984. Diseases of field crops in Canada. Canadian Phytopathological Society.

Schena, L., Nigro, F., Ippolito, A. and Gallitelli, D. 2004. Realtime quantitative PCR: A new technology to detect and study phytopathogenic and antagonistic fungi. Eur. J. Plant Pathol. 110:893-908.

Walcott, R. R. 2003. Detection of seedborne pathogens. HortTechnology 13:40-47.

Wallwork, H. 1992. Cereal leaf and stem diseases. In Grains Research and Development Corporation.

Young, J. M., Dye, D. W. and Wilkie, J. P. 1978. Genus VII. Pseudomonas Migula 1894. New Zealand J. Agric. Res. 21:153-177. 